\title{
ANALISIS RELEVANSI INFORMASI, RELIABILITAS, DAN ASIMETRI INFORMASI SETELAH PENGADOPSIAN IFRS (STUDI PADA PERUSAHAAN MANUFAKTUR YANG TERDAFTAR DI BEI TAHUN 2009-2014)
}

\author{
Shella Yolan Anggraini ${ }^{1}$, Nadirsyah ${ }^{* 2}$ \\ ${ }^{1,2}$ Program Studi Akuntansi Fakultas Ekonomi Universitas Syiah Kuala \\ e-mail: nadirsyah@unsyiah.ac.id ${ }^{* 2}$
}

\section{* Corresponding Author}

\begin{abstract}
The objectives of the research are to examine the impact of adoption of IFRS in Indonesia on quality of financial statement information in terms of relevance and reliability and to examines information asymetry. The Relevance is measured by combined value relevance of book value of equity and net income, reliability is measured by absolute discretionary accrual as an inverse measure, and information asymetry is measured by bid ask spread. Data were collected from the financial statements of the manufacture companies that listed at Indonesia Stock Exchange. Research conduct in 6 years (2009-2014). By using purposive sampling and balanced panel data, there are 31 companies fulfilling the sample criteria. Multiple linier regression and paired sample t-test model is used to test the hypothesis. The results showed that there is an increasing quality of financial statement information after the adoption of IFRS but no difference in information asymmetry after the adoption of IFRS
\end{abstract}

Keywords: IFRS, Relevance, Reliability, Information Asymmetry

\section{Pendahuluan}

Laporan keuangan yang disusun oleh perusahaan haruslah berisikan informasi yang akurat dan relevan atas kegiatan perusahaan, sehingga informasi tersebut dapat berguna bagi pengambilan keputusan. Dengan kata lain, informasi yang disajikan dalam laporan keuangan haruslah informasi yang berkualitas. Saito dan Mayangsari (2009) menyatakan bahwa standar akuntansi yang berkualitas akan mempengaruhi kualitas informasi dari laporan keuangan perusahaan.

Semakin meningkatnya kebutuhan terhadap standar yang berkualitas secara international menjadi alasan dibentuknya International Accounting Standard Comitte (IASC) pada tahun 1973 dimana pada tahun 2001 IASC tersebut digantikan dengan International Accounting Standard Board (IASB). Standar-standar akuntansi yang dibentuk oleh IASB adalah principle based standards yang disebut dengan International Financial Accounting Standard (IFRS), sehingga saat ini IFRS telah menjadi standar pelaporan keuangan yang berlaku secara internasional termasuk di Indonesia (Wahidah dan Ayem, 2014).
Walaupun IFRS dibentuk dengan tujuan meningkatkan kualitas informasi dari laporan keuangan, namun terdapat perbedaan secara konseptual mengenai dampak dari penerapan IFRS. Muncul argumentasi bahwa IFRS dapat meningkatkan kualitas informasi akuntansi karena penggunaan nilai wajar (fair value) lebih dapat merefleksikan kondisi ekonomik perusahaan, sehingga kualitas informasi akuntansi dapat meningkat (Barth et al., 2008). Disamping itu, muncul pula argumentasi dari Cahyonowati dan Ratmono (2012) serta Rahmawati dan Murtini (2015) menyatakan dengan adanya fleksibilitas dalam principles-based standards dapat memberikan kesempatan yang lebih besar bagi perusahaan untuk melakukan tindakan manajemen laba, sehingga kualitas informasi dapat menurun.

Informasi dapat dikatakan sebagai informasi yang berkualitas apabila memenuhi karakteristik kualitatif informasi akuntansi yaitu relevansi, reliabilitas, komparabilitas, dan konsistensi (Kieso et al., 2007:37-38). Oleh karenanya, penelitian ini menguji dampak adopsi IFRS terhadap kualitas informasi yang berupa relevansi dan reliabilitas. 
Relevansi adalah kemampuan informasi untuk membantu pemakai dalam membedakan beberapa alternatif atau pilihan keputusan sehingga pemakai dapat dengan mudah mengambil keputusan yang tepat (Soewardjono, 2011:169). Reliabilitas adalah Informasi tersebut merupakan informasi yang menggambarkan dengan jujur transaksi dan peristiwa lainnya yang seharusnya disajikan secara wajar sehingga informasi dapat diandalkan untuk dijadikan dasar pertimbangan dalam pengambilan suatu keputusan (Krismiaji et al., 2013).

Edvandini et al. (2014) menyatakan bahwa bila kualitas informasi laporan keuangan meningkat maka asimetri informasi menurun. Cahyati (2011) berpendapat bahwa pada dasarnya tujuan dari standar akuntansi internasional atau IFRS yakni untuk mengurangi tingkat asimetri informasi. Asimetri Informasi muncul ketika manajer lebih mengetahui informasi internal dan prospek perusahaan di masa yang akan datang dibandingkan pemegang saham dan stakeholder lainnya (Novianto dan Cahyonowati, 2014). Melalui pengadopsian IFRS dapat membuat manajemen untuk mengungkapkan informasi secara lebih rinci dan detail, sehingga mendekati dengan pengungkapan penuh (full disclosure). Tingkat pengungkapan yang semakin mendekati pengungkapan penuh dapat mengurangi asimetri informasi (ketidakseimbangan informasi) antara manajer dengan pihak pengguna laporan keuangan.

\section{Kerangka Pemikiran Dan Hipotesis Hubungan Pengadopsian IFRS dengan Relevansi Informasi}

IAI mengungkapkan bahwa pengadopsian IFRS diharapkan dapat meningkatkan relevansi nilai bagi investor,oleh karenanya IFRS memiliki pengaruh yang sangat besar bagi peningkatan relevansi informasi yang terkandung dalam laporan keuangan. Informasi dalam laporan keuangan memiliki relevansi nilai jika informasi tersebut dapat dijadikan dasar untuk memprediksi nilai pasar perusahaan (Kargin 2013). Menurut Rahmawati dan Murtini (2015) IFRS dengan principles-based standards lebih dapat meningkatkan relevansi nilai informasi akuntansi. Pengukuran dengan fair value lebih dapat menggambarkan posisi dan kinerja ekonomik perusahaan.
Hasil penelitian Iatridis (2010) menunjukkan bahwa setelah pengadopsian IFRS nilai relevansi semakin meningkat dibandingkan dengan sebelum adopsi IFRS. Chebane dan Othman (2014) juga melakukan penelitian untuk menguji dampak adopsi IFRS terhadap tingkat relevansi di Asia dan Afrika, dan hasilnya menunjukkan hal yang serupa bahwa relevansi informasi semakin meningkat setelah pengadopsian IFRS. Barth et al. (2008) melakukan penelitian yang hasilnya juga terjadi peningkatan kualitas informasi yang ditandai dengan meningkatnya nilai relevansi informasi.

\section{Hubungan Pengadopsian IFRS dengan Reliabilitas}

IFRS berpengaruh besar terhadap peningkatan kualitas informasi, salah satunya berpengaruh terhadap reliabilitas.Informasi dikatakan reliable apabila informasi tersebut mampu untuk memberikan keyakinan bahwa informasi tersebut benar atau valid (Soewardjono, 2011:168). Reliabilitas informasi akuntansi dalam penelitian ini diwakili oleh faithful representation. Informasi yang faithful representation adalah informasi menggambarkan dengan jujur transaksi serta peristiwa lainnya yang seharusnya disajikan atau yang secara wajar dapat diharapkan untuk disajikan sehingga informasi bisa diandalkan sebagai dasar pertimbangan pengambilan keputusan. Informasi faktual dapat diperoleh apabila angka-angka dalam laporan keuangan menyajikan keadaan yang sebenarnya (Wahidah dan Ayem, 2014). Dalam penelitian Krismiaji et al. (2013) faithfull representation diwakili dengan nilai ABSDA atau absolut discretionary accrual).

Barth et al. (2008) melakukan penelitian dampak dari adopsi IFRS terhadap tingkat manajemen laba dan hasilnya menunjukkan bahwa manajemen laba setelah adopsi IFRS semakin menurun dibandingkan dengan sebelum adopsi IFRS. Hasil penelitian yang sama juga ditunjukkan oleh penelitian Christensen et al. (2015) dan penelitian Chen et al. (2010) yang menunjukkan bahwa tingkat manajemen laba semakin menurun setelah adopsi IFRS.

Hasil penelitian Wahidah dan Ayem (2014) menunjukkan bahwa pengaruh pengadopsian International Financial Reporting Standard (IFRS) terhadap reliabilitas informasi akuntansi menunjukkan bahwa IFRS berpengaruh positif dan signifikan. Hasil penelitian Krismiaji et al. (2013) juga menunjukkan 
hal yag sama yakni penerapan IFRS berpengaruh positif terhadap tingkat reliabilitas.

\section{Hubungan Pengadopsian IFRS dengan Asimetri Informasi}

Adopsi IFRS menuntut manajemen untuk mengungkapkan informasi akuntansi lebih rinci dan detail. Pengungkapan dalam laporan keuangan harus sejalan dengan informasi yang dipakai untuk pengambilan keputusan yang diambil oleh manajemen. Tingkat pengungkapan yang lebih rinci dan detail mendekati pengungkapan penuh (full disclosure) akan mengurangi tingkat asimetri informasi akuntansi antara manajer dan pengguna laporan keuangan.

Pada penelitian Edvandini et al. (2014) menghasilkan pengujian asimetri informasi setelah adopsi IFRS yang menunjukkan bahwa asimetri informasi mengalami penurunan. Pada penelitian
Gesson dan Sellhorn (2006) juga menguji tingkat asimetri informasi selama GAAP dan selama IFRS, dan hasil penelitian menunjukkan bahwa tingkat asimetri informasi semakin menurun setelah pengadopsian IFRS. Pada penelitian Muller et al. (2011) yang dilakukan di Eropa, dan didapatkan hasil bahwa konvergensi IFRS ini berpengaruh negatif terhadap asimetri informasi dimana dengan menerapkan IFRS ini pada perusahaan maka nilai asimetri informasi tersebut akan menurun.Diharapkan setelah pengadopsian penuh IFRS maka dapat menurunkan tingkat asimetri informasi akuntansi.

Berikut disajikan kerangka pemikiran teoritis yang dituangkan dalam model penelitian seperti yang ditunjukan pada Gambar 2.1.

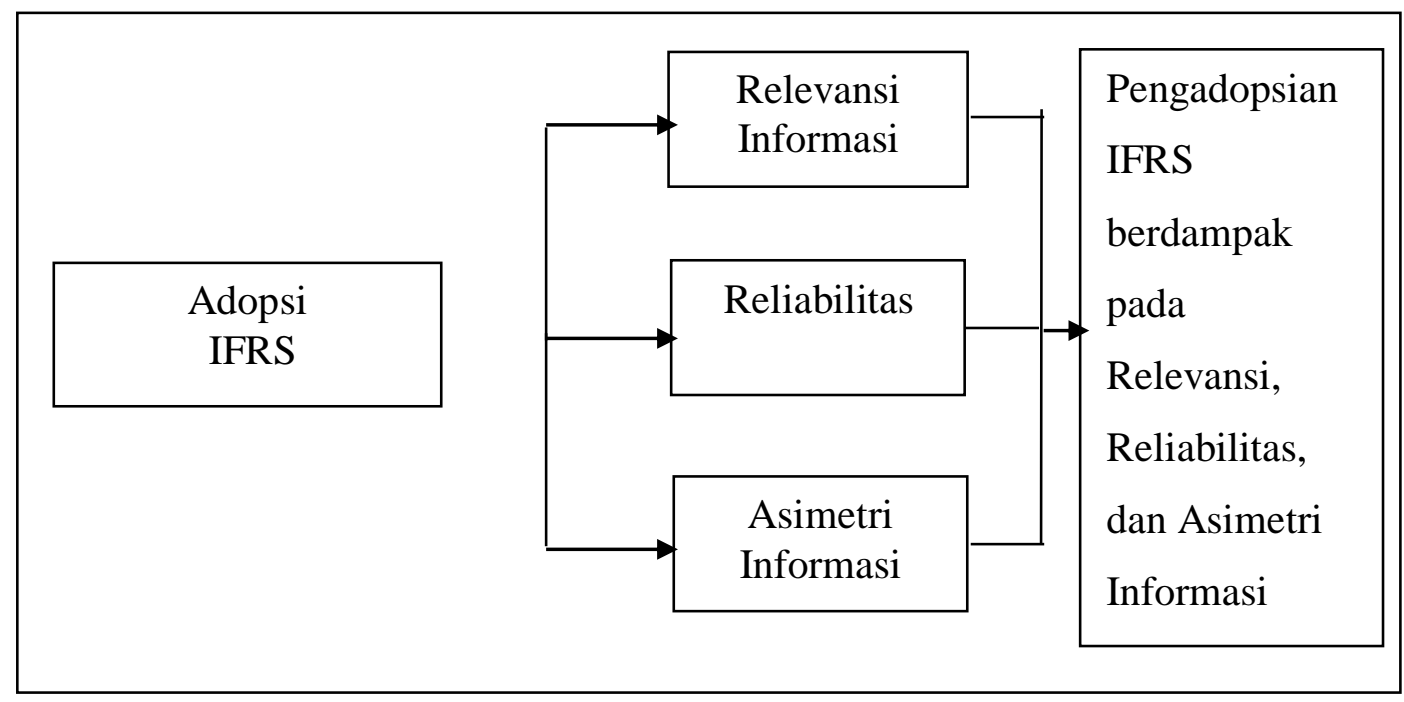

Gambar 2.1 Skema Kerangka Pemikiran

\section{Hipotesis}

H1: Terjadi peningkatan relevansi informasi setelah pengadopsian IFRS

H2: Pengadopsian IFRS berpengaruh terhadap reliabilitas dan terjadi peningkatan reliabilitas setelah adopsi IFRS.

H3: Terjadi penurunan asimetri informasi setelah pengadopsian IFRS.

\section{Metode Penelitian}

\section{Populasi dan Sampel Penelitian}

Populasi yang digunakan dalam penelitian ini adalah perusahaan manufaktur yang berturut-turut terdaftar di BEI selama tahun 2009-2014. Pengambilan sampel pada penelitian ini menggunakan metode purposive sampling yaitu pengambilan sampel sesuai dengan kriteria tertentu atau sesuai dengan tujuan tertentu. Kriteria-kriteria tersebut: 


\begin{tabular}{|l|c|}
\hline \multicolumn{1}{|c|}{ Kriteria Populasi Sasaran } & Jumlah Perusahaan \\
\hline Jumlah perusahaan manufaktur yang terdaftar dari tahun 2009-2014 & 121 \\
Perusahaan yang tidak dapat diakses laporan keuangannya. & $(50)$ \\
Perusahaan yang tergabung kedalam satu jenis perusahaan & $(1)$ \\
Perusahaan yang tidak menyajikan laporan keuangan dalam rupiah & $(20)$ \\
Perusahaan yang mengalami kerugian & $(17)$ \\
Perusahaan yang melakukan IPO setelah tahun 2009 & $(2)$ \\
\hline \multicolumn{1}{|c|}{ Total Sampel } & $\mathbf{3 1}$ \\
\hline
\end{tabular}

\section{Metode Analisis dan Rancangan Pengujian Hipotesis}

Hipotesis diuji dengan menggunakan metode analisis statistik deskriptif, regresi linier berganda, dan uji paired sample t-test. Sebelumnya dilakukan uji asumsi klasik terlebih dahulu. Uji asumsi klasik terdiri dari uji normalitas, uji multikolieritas, uji heterokedastisitas, dan uji autokorelasi. Sebelum melakukan uji paired sample t-test, maka melakukan uji normalitas dan uji homogenitas.

Untuk menguji Relevansi Informasi:

$$
\mathrm{Pi}_{\mathrm{t}}=\boldsymbol{\beta}_{0}+\beta_{1} \mathrm{EPS}_{\mathrm{it}}+\boldsymbol{\beta}_{2} \mathrm{BVPS}_{\mathrm{it}}+\varepsilon
$$

Keterangan:

$\mathrm{Pi}_{\mathrm{t}} \quad$ : Harga saham perusahaan i pada saat penutupan

EPS $_{\text {it }} \quad$ : Laba bersih per saham (earnings per share) perusahaan i tahun $\mathrm{t}$

BVPS $_{\mathrm{it}}$ : Nilai buku ekuitas per saham (book value per share) perusahaan i tahun $\mathrm{t}$

\section{\& : Error term}

Untuk menguji Reliabilitas:

$\operatorname{ABSDA}=\beta_{0}+\beta_{1} \mathrm{ROA}+\boldsymbol{\beta}_{2} \mathrm{UP}+\boldsymbol{\beta}_{3} \mathrm{MBV}+\boldsymbol{\beta}_{4} \mathrm{~L}+\varepsilon$

Keterangan :

ABSDA $=$ Nilai absolut akrual diskresi

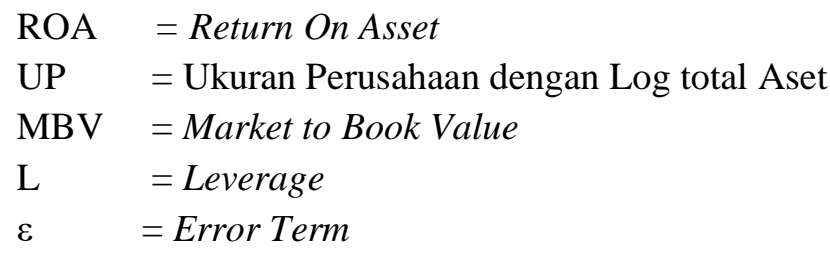

Untuk menguji Asimetri Informasi:

$$
\begin{gathered}
\text { Spread }_{\text {it }}= \\
\left(\left(\text { ask price }_{i t}-\text { bid price }_{i t}\right) /\left(\left(\text { ask price }_{\text {it }}+\right.\right.\right. \\
\text { bid price } \left.\left.\left._{i t}\right) / 2\right)\right) \times 100
\end{gathered}
$$

Keterangan :

Spread $_{i t}=$ Selisih harga saat ask dengan harga saat bid

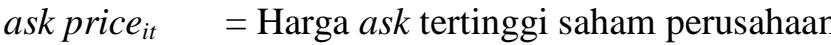
i pada tahun $\mathrm{t}$

bid $_{\text {price }}{ }_{i t} \quad=$ Harga bid terendah saham perusahaan i pada tahun $\mathrm{t}$

\section{Hasil Pengujian Hipotesis Dan Pembahasan Relevansi}

Uji Normalitas Data

Tabel 4.2

Uji Normalitas Data

One-Sample Kolmogorov-Smirnov Test

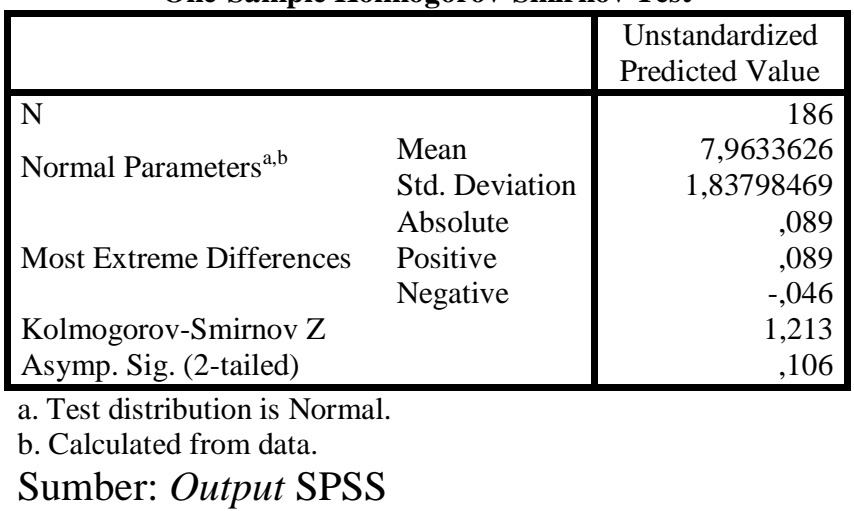

Berdasarkan tabel tersebut, nilai signifikansi 0,106 yang berarti > 0,05 . Oleh karenanya, data tersebut berdistribusi normal.

\section{Uji Multikolinearitas}

Berdasarkan Tabel 4.3, dapat dilihat bahwa nilai tolerance variabel secara keseluruhan $>0,10$ dan nilai VIF <10. Hal ini menggmabarkan bahwa penelitian ini tidak terdapat multikolinieritas atau tidak terdapat korelasi setiap variabel bebas yang digunakan. 
Tabel 4.3

Uji Multikolinearitas

\begin{tabular}{|c|c|c|c|c|c|c|c|c|}
\hline \multirow{3}{*}{ Mod } & \multicolumn{8}{|c|}{ Coefficients $^{\mathrm{a}}$} \\
\hline & & \multicolumn{2}{|c|}{$\begin{array}{l}\text { Unstandardized } \\
\text { Coefficients }\end{array}$} & $\begin{array}{l}\text { Standardized } \\
\text { Coefficients }\end{array}$ & \multirow[t]{2}{*}{$\mathrm{t}$} & \multirow[t]{2}{*}{ Sig. } & \multicolumn{2}{|c|}{ Collinearity Statistics } \\
\hline & & $\mathrm{B}$ & Std. Error & Beta & & & Tolerance & VIF \\
\hline \multirow{3}{*}{1} & (Constant) & 2,324 & ,309 & & 7,518 &, 000 & & \\
\hline & EPS &, 814 & 063 & 817 & 12,915 & ,000 &, 143 & 7,015 \\
\hline & BVPS & , 180 & 082 & 138 & 2,187 & ,030 & ,143 & 7,015 \\
\hline
\end{tabular}

a. Dependent Variable: Harga Saham

Sumber: Output SPSS

\section{Uji Heterokedastiditas}

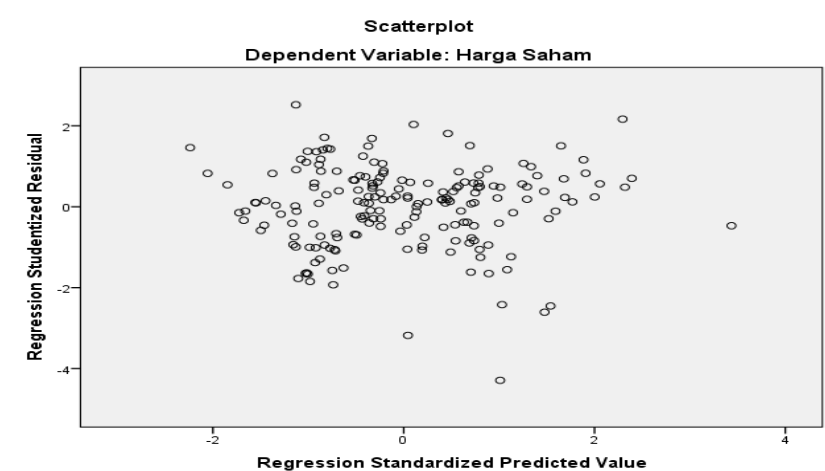

\section{Sumber: Output SPSS}

Berdasasrkan Gambar 4.1. tersebut, dapat dilihat bahwa titik-titik menyebar secara merata diatas angka 0 dan dibawah angka 0 pada sumbu y, sehingga dapat dikatakan bahwa tidak terjadi heterokedastisitas.

\section{Uji Autokorelasi}

Gambar 4.1 Uji Heterokedastiditas

Tabel 4.4

Uji Autokorelasi

Model Summary ${ }^{\mathbf{b}}$

\begin{tabular}{|l|r|r|r|r|r|}
\hline Model & \multicolumn{1}{|c|}{ R } & R Square & Adjusted R Square & Std. Error of the Estimate & Durbin-Watson \\
\hline 1 &, $946^{\mathrm{a}}$ &, 896 &, 894 &, 6308160 & 2,035 \\
\hline
\end{tabular}

a. Predictors: (Constant), BVPS, EPS

Sumber: Output SPSS

b. Dependent Variable: Harga Saham

Dalam penelitian ini, autokorelasi dihitung menggunakan uji DurbinWatson (DW). Hasil uji autokorelasi dapat dilihat pada Tabel 4.4, bahwa nilai DW Test sebesar 2,035. Dengan nilai DW Test yang dimiliki, berarti nilai tersebut berada diantara $\mathrm{dU}<\mathrm{dw}$
$<4-$ dU atau $1,789<2,035<2,211$. Maka berarti tidak terjadi autokorelasi.

Hasil Pengujian Hipotesis

Sebelum Adopsi IFRS

Tabel 4.5

\section{Analisis Regresi Berganda Sebelum Adopsi IFRS}

Coefficients ${ }^{\mathrm{a}}$

\begin{tabular}{|c|c|c|c|c|c|c|}
\hline \multirow{2}{*}{\multicolumn{2}{|c|}{ Model }} & \multicolumn{2}{|c|}{ Unstandardized Coefficients } & \multirow{2}{*}{$\frac{\text { Standardized Coefficients }}{\text { Beta }}$} & \multirow[t]{2}{*}{$\mathrm{T}$} & \multirow[t]{2}{*}{ Sig. } \\
\hline & & $\mathrm{B}$ & Std. Error & & & \\
\hline \multirow{3}{*}{1} & (Constant) & 1,954 & ,487 & & 4,015 & 000 \\
\hline & EPS &, 810 &, 114 & ,795 & 7,115 & 000 \\
\hline & BVPS & 210 & 146 & ,161 & 1,444 & 152 \\
\hline
\end{tabular}

a. Dependent Variable: Harga Saham

Sumber: Output SPSS 
Berdasarkan Tabel 4.5 persamaan regresi yang dapat disusun adalah:

$$
\mathrm{Pi}_{\mathrm{t}}=1,954+0,810 \mathrm{EPS}_{\mathrm{it}}+0,210 \mathrm{BVPS}_{\mathrm{it}}+\varepsilon
$$

\section{Setelah Adopsi IFRS}

Tabel 4.6

\section{Analisis Regresi Berganda Sebelum Adopsi IFRS}

Coefficients $^{\mathrm{a}}$

\begin{tabular}{|c|c|c|c|c|c|c|}
\hline \multirow{2}{*}{\multicolumn{2}{|c|}{ Model }} & \multicolumn{2}{|c|}{ Unstandardized Coefficients } & \multirow{2}{*}{$\frac{\text { Standardized Coefficients }}{\text { Beta }}$} & \multirow[t]{2}{*}{$\mathrm{t}$} & \multirow[t]{2}{*}{ Sig. } \\
\hline & & $\mathrm{B}$ & Std. Error & & & \\
\hline \multirow{3}{*}{1} & (Constant) & 2,988 & ,391 & & 7,635 & 000 \\
\hline & EPS &, 871 & 071 & ,903 & 12,282 &, 000 \\
\hline & BVPS & 070 & 095 &, 054 & ,741 & ,461 \\
\hline
\end{tabular}

a. Dependent Variable: Harga Saham

Sumber: Output SPSS

Berdasarkan Tabel 4.6 persamaan regresi yang dapat disusun adalah:

\section{Koefisien Determinasi (R2)}

$$
\mathrm{Pi}_{\mathrm{t}}=2,988+0,871 \mathrm{EPS}_{\mathrm{it}}+0,070 \mathrm{BVPS}_{\mathrm{it}}+\varepsilon
$$

Tabel 4.7

Nilai Koefisien Determinasi

\begin{tabular}{|c|c|c|}
\hline & Sebelum Adopsi IFRS & Sesudah Adopsi IFRS \\
\hline Adjusted $R^{2}$ & 0,901 & 0,904 \\
\hline
\end{tabular}

Nilai adjusted $R^{2}$ untuk periode sbelum adopsi IFRS sebesar 0,901 atau $90,1 \%$. Hal tersebut menandakan bahwa perubahan harga saham dapat dijelaskan oleh variabel independen yang berupa earning per share dan book value per share sebesar $90,1 \%$, sedangkan sisanya $9,9 \%$ dijelaskan oleh variabel lain. Pada periode setelah adopsi IFRS diperoleh nilai adjusted $\mathrm{R}^{2}$ sebesar 0,904 atau 90,4\%.
Hal tersebut berarti perubahan harga saham dapat dijelaskan oleh variabel independen yang berupa earning per share dan book value per share sebesar $90,4 \%$, sedangkan sisanya yakni 9,6 \% dijelaskan oleh variabel lain.

\section{Reliabilitas}

Uji Normalitas Data

Tabel 4.8

Uji Normalitas Data

One-Sample Kolmogorov-Smirnov Test

\begin{tabular}{|ll|r|}
\hline & & \multicolumn{1}{|c|}{ Unstandardized Residual } \\
\hline Normal Parameters & & 186 \\
& Mean & $0 \mathrm{E}-7$ \\
& Std. Deviation &, 46915970 \\
Most Extreme Differences & Absolute &, 067 \\
& Positive &, 067 \\
Kolmogorov-Smirnov Z & Negative &,- 063 \\
Asymp. Sig. (2-tailed) & &, 914 \\
\hline
\end{tabular}

a. Test distribution is Normal.

b. Calculated from data.

Sumber: Output SPSS 
Berdasarkan tabel tersebut, nilai signifikansi 0,374 yang berarti $>0,05$. Oleh karenanya, data tersebut berdistribusi normal.

\section{Uji Multiokolinearitas}

Tabel 4.9

Uji Multikolinearitas

Coefficients $^{\mathrm{a}}$

\begin{tabular}{|c|c|c|c|c|c|c|c|c|}
\hline \multirow{2}{*}{\multicolumn{2}{|c|}{ Model }} & \multicolumn{2}{|c|}{ Unstandardized Coefficients } & \multirow{2}{*}{$\frac{\text { Standardized Coefficients }}{\text { Beta }}$} & \multirow[t]{2}{*}{$\mathrm{T}$} & \multirow[t]{2}{*}{ Sig. } & \multicolumn{2}{|c|}{ Collinearity Statistics } \\
\hline & & $\mathrm{B}$ & Std. Error & & & & Tolerance & VIF \\
\hline \multirow{5}{*}{1} & (Constant) &,- 183 & ,598 & &,- 306 & ,760 & & \\
\hline & ROA &, 854 & ,226 & ,268 & 3,773 &, 000 & ,969 & 1,032 \\
\hline & UP &,- 034 & 021 &,- 117 & $-1,604$ &, 110 & ,912 & 1,097 \\
\hline & MBV &, 223 & ,093 & , 175 & 2,402 &, 017 & ,921 & 1,086 \\
\hline & $\mathrm{L}$ &,- 081 &, 120 &,- 047 &,- 673 & ,502 & ,980 & 1,021 \\
\hline
\end{tabular}

Sumber: Output SPSS

Berdasarkan Tabel 4.3, dapat dilihat bahwa nilai tolerance variabel secara keseluruhan $>0,10$ dan nilai VIF $<10$. Hal ini menggmabarkan bahwa penelitian ini tidak terdapat multikolinieritas atau tidak terdapat korelasi setiap variabel bebas yang digunakan.

\section{Uji Heterokedastiditas}

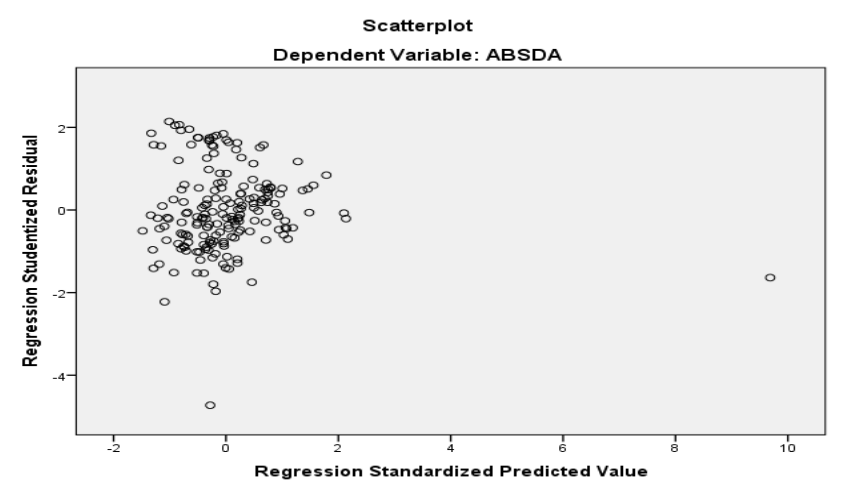

Gambar 4.2 Uji Heterokedastidittas
Berdasasrkan Gambar 4.2. tersebut, dapat dilihat bahwa titik-titik menyebar secara merata diatas angka 0 dan dibawah angka 0 pada sumbu y, sehingga dapat dikatakan bahwa tidak terjadi heterokedastisitas.

\section{Uji Autokorelasi}

Tabel 4.10

Uji Autokorelasi

\begin{tabular}{l|r|r|r|r|r|}
\hline Model & $\mathrm{R}$ & $\mathrm{R}$ Square & $\begin{array}{c}\text { Adjusted R } \\
\text { Square }\end{array}$ & $\begin{array}{c}\text { Std. Error of the } \\
\text { Estimate }\end{array}$ & Durbin-Watson \\
\hline 1 &, $344^{\mathrm{a}}$ &, 119 &, 099 &, 47432 & 1,790 \\
\hline
\end{tabular}
a. Predictors: (Constant), L, MBV, ROA, UP
b. Dependent Variable: ABSDA

Dari tabel tersebut dapat dilihat bahwa nilai DW 1,790. Karena nilai DU sebesar 1,771 yang berarti lebih kecil dari nilai DW, dan nilai DW lebih kecil dari nilai 4-DU yakni sebesar 2,229 atau dengan kata lain
$1,771<1,790<2,229$ maka dapat disimpulkan bahwa tidak terjadi autokorelasi.

Uji Normalitas Sebelum Uji Paired Sample T-test 
Tabel 4.11

Uji Normalitas

One-Sample Kolmogorov-Smirnov Test

\begin{tabular}{|c|c|c|}
\hline & & ABSDA \\
\hline $\mathrm{N}$ & & 186 \\
\hline Normal Parameters, & Mean &,- 9593 \\
\hline Normal Parameters & Std. Deviation & ,49973 \\
\hline & Absolute & 045 \\
\hline Most Extreme Differences & Positive & 037 \\
\hline & Negative &,- 045 \\
\hline Kolmogorov-Smirnov Z & & 616 \\
\hline Asymp. Sig. (2-tailed) & & 843 \\
\hline
\end{tabular}

Berdasarkan tabel tersebut, diketahui bahwa nilai signifikansi 0,843 yang berarti lebih besar dari atau $>0,05$, sehingga dapat diartikan data berdistribusi normal.

\section{Uji Homogenitas}

Tabel 4.12

Uji Homogenitas

Test of Homogeneity of Variances

ABSDA

\begin{tabular}{|c|c|c|c|}
\hline Levene Statistic & df1 & df 2 & Sig. \\
\hline 223 & 1 & 184 & 638 \\
\hline
\end{tabular}

\section{Sumber: Output SPSS}

Berdasarkan tabel tersebut, diketahui bahwa nilai signifikansi 0,638 yang berarti lebih besar dari atau $>0,05$, sehingga dapat diartikan data berdistribusi memiliki varian yang sama.

Hasil Pengujian Hipotesis

Analisis Regresi Berganda

Tabel 4.13

Hasil Regresi Berganda Reliabilitas

Coefficients $^{\mathrm{a}}$

\begin{tabular}{|c|c|c|c|c|c|c|}
\hline \multirow{2}{*}{\multicolumn{2}{|c|}{ Model }} & \multicolumn{2}{|c|}{ Unstandardized Coefficients } & Standardized Coefficients & \multirow[t]{2}{*}{$\mathrm{T}$} & \multirow[t]{2}{*}{ Sig. } \\
\hline & & B & Std. Error & Beta & & \\
\hline \multirow{5}{*}{1} & (Constant) &,- 183 &, 598 & &,- 306 &, 760 \\
\hline & ROA & ,854 & ,226 & ,268 & 3,773 &, 000 \\
\hline & UP &,- 034 &, 021 &,- 117 & $-1,604$ &, 110 \\
\hline & MBV & ,223 & ,093 & , 175 & 2,402 & ,017 \\
\hline & L &,- 081 & , 120 &,- 047 &,- 673 &, 502 \\
\hline
\end{tabular}

Melalui Tabel 4.17 menunjukkan koefisien ROA memiliki koefisien positif yaitu 0,854 dengan signifikansi 0,000 . Secara statistik variabel ROA berpengaruh positif terhadap variabel dependen ABSDA.

Uji Paired Sample T-test ABSDA

Tabel 4.14

Hasil Uji Paired Sample T-Test Absda

Paired Samples Test

\begin{tabular}{|c|c|c|c|c|c|c|c|c|c|}
\hline & & \multicolumn{5}{|c|}{ Paired Differences } & \multirow[t]{3}{*}{$\mathrm{t}$} & \multirow[t]{3}{*}{$\mathrm{df}$} & \multirow{3}{*}{$\begin{array}{c}\text { Sig. } \\
(2- \\
\text { tailed) }\end{array}$} \\
\hline & & \multirow[t]{2}{*}{ Mean } & \multirow[t]{2}{*}{$\begin{array}{c}\text { Std. } \\
\text { Deviation }\end{array}$} & \multirow[t]{2}{*}{$\begin{array}{l}\text { Std. Error } \\
\text { Mean }\end{array}$} & \multicolumn{2}{|c|}{$\begin{array}{c}95 \% \text { Confidence Interval } \\
\text { of the Difference }\end{array}$} & & & \\
\hline & & & & & Lower & Upper & & & \\
\hline Pair 1 & $\begin{array}{l}\text { Sebelum IFRS - } \\
\text { Sesudah IFRS }\end{array}$ & ,2117331 & ,6743200 & ,0699237 & 0728585 & ,3506076 & 3,028 & 92 & 003 \\
\hline
\end{tabular}

Melalui Tabel 4.14 menunjukkan bahwa nilai signifikansi sebesar 0,003 yang berarti lebih kecil dari
0,05 sehingga dapat diartikan bahwa setelah adopsi IFRS terdapat penurunan manajemen laba, sehingga 
hal ini dapat diartikan juga bahwa tingkat reliabilitas telah meningkat pada periode setelah adopsi IFRS.

\section{Asimetri Informasi}

Uji Normalitas Data

Tabel 4.15

Uji Normalitas Data

\begin{tabular}{|r|r|r|r|r|r|r|r|}
\hline & \multirow{2}{*}{ Time } & \multicolumn{3}{|c|}{ Kolmogorov-Smirnov $^{\text {a }}$} & \multicolumn{3}{|c|}{ Shapiro-Wilk } \\
\cline { 3 - 8 } & & Statistic & df & \multicolumn{1}{c|}{ Sig. } & Statistic & \multicolumn{1}{c|}{ df } & \multicolumn{1}{c|}{ Sig. } \\
\hline \multirow{2}{*}{ Spread } & Sebelum IFRS &, 066 & 93 &, $200^{*}$ &, 975 & 93 &, 071 \\
& Sesudah IFRS &, 054 & 93 &, $200^{*}$ &, 992 & 93 &, 852 \\
\hline
\end{tabular}

*. This is a lower bound of the true significance.

a. Lilliefors Significance Correction

Berdasarkan Tabel 4.20 tersebut menunjukkan nilai signifikansi untuk data sebelum IFRS sebesar 0,071 dan untuk data sesudah IFRS 0,852 . Nilai-nilai signifikansi tersebut lebih besar dari 0,05 $(0,07>0,05$ dan $0,852>0,05)$, sehingga dapat dikatakan data spread untuk menguji asimetri informasi sebelum dan sesudah IFRS berdistribusi normal.

\section{Uji Homogenitas}

Tabel 4.16

Uji Homogenitas

\begin{tabular}{|c|c|c|c|}
\hline Spread & & & \\
\hline Levene Statistic & df1 & df2 & Sig. \\
\hline, 043 & 1 & 184 & 836 \\
\hline
\end{tabular}

Berdasarkan tabel tersebut diketahui bahwa nilai signifikansi 0,836 yang berarti nilai tersebut lebih besar dari $0,05(0,836>0,05)$, sehingga dapat diindikasikan bahwa data mempunyai varian yang sama.

\section{Hasil Pengujian Hipotesis}

\section{Tabel 4.17}

Uji Paired Sample T-Test Asimetri Informasi

Paired Samples Test

\begin{tabular}{|c|c|c|c|c|c|c|c|c|c|}
\hline & & \multicolumn{5}{|c|}{ Paired Differences } & \multirow[t]{3}{*}{$\mathrm{t}$} & \multirow[t]{3}{*}{$\mathrm{df}$} & \multirow{3}{*}{$\begin{array}{l}\text { Sig. (2- } \\
\text { tailed) }\end{array}$} \\
\hline & & \multirow[t]{2}{*}{ Mean } & \multirow[t]{2}{*}{$\begin{array}{c}\text { Std. } \\
\text { Deviation }\end{array}$} & \multirow[t]{2}{*}{$\begin{array}{l}\text { Std. Error } \\
\text { Mean }\end{array}$} & \multicolumn{2}{|c|}{$\begin{array}{l}95 \% \text { Confidence Interval } \\
\text { of the Difference }\end{array}$} & & & \\
\hline & & & & & Lower & Upper & & & \\
\hline Pair & $\begin{array}{l}\text { Sebelum IFRS - } \\
\text { Sesudah IFRS }\end{array}$ &,- 0072822 & ,5978953 & 061998 &,- 1304172 & ,1158529 &,- 117 & 92 & ,907 \\
\hline
\end{tabular}

Berdasarkan Tabel 4.17 nilai signifikansi ratarata bid-ask spread sebelum dan setelah penerapan IFRS sebesar 0,907. Hal ini menunjukkan bahwa nilai signifikansi lebih besar dari $0.05(0,907>0,05)$ yang berarti tidak terdapat perbedaan asimetri informasi sebelum penerapan IFRS dan setelah penerapan IFRS atau dengan kata lain tidak terjadi penurunan asimetri informasi setelah adopsi IFRS.

\section{Dampak Pengadopsian IFRS terhadap Relevansi Informasi}

Dalam pengujian relevansi ini, didapatkan bahwa terjadi kenaikan nilai relevansi pada periode setelah adopsi IFRS dilihat dari perbandingan nilai Adjusted $R^{2}$ yang meningkat, sehingga hal ini membuktikan bahwa adopsi IFRS di Indonesia mempengaruhi nilai relevansi yang diukur dengan laba bersih per lembar saham (earning per share) dan nilai buku per lembar saham (book value per share). Pengambilan kesimpulan dengan mendasarkan pada adjusted $R^{2}$ adalah untuk efek kombinasi kedua proksi informasi akuntansi yaitu laba bersih dan nilai buku ekuitas (Karampinis dan Hevas, 2011). Bukti empiris ini mendukung hipotesis bahwa pengadopsian IFRS berpengaruh terhadap relevansi informasi yang dilihat dari peningkatan nilai relevansi.

\section{Dampak Pengadopsian IFRS terhadap Reliabilitas}

Hasil pengujian dalam penelitian ini membuktikan bahwa adopsi IFRS di Indonesia 
mempengaruhi tingkat reliabilitas yang diwakili dengan faithfull representation. Didapatkan hasil bahwa koefisien ROA berpengaruh positif terhadap ABSDA, sehingga dapat diambil kesimpulan bahwa pengadopsian IFRS yang diwakili dengan ROA berpengaruh positif terhadap reliabilitas yang diwakili dengan faithfull representation.

Selain itu, untuk menguji tingkat reliabilitas juga dapat dilihat dari penurunan angka manajemen laba. Setelah dilakukan pengujian maka dibuktikan bahwa setelah adopsi IFRS terjadi penurunan manajemen laba. Bila angka manajemen laba menurun, maka tingkat reliabilitas meningkat. Oleh karenanya dapat dinyatakan bahwa adopsi IFRS berpengaruh dalam peningkatan reliabilitas. Hal ini dikarenakan dengan adanya pengetatan standar akuntansi sehingga dapat menurunkan angka manajemen laba. Selain itu, karena IFRS merupakan standar dengan nilai wajar (fair value) sehingga lebih dapat merefleksikan kondisi ekonomik perusahaan yang sesunggguhnya, dimana pada akhirnya level atau tingkat manajemen laba akan berkurang.

\section{Dampak Pengadopsian IFRS terhadap Asimetri Informasi}

Hasil pengujian dalam penelitian ini membuktikan bahwa tidak terjadi penurunan asimetri informasi setelah pengadopsian IFRS, dimana berarti tidak terdapat pengaruh dari pengadopsian IFRS terhadap asimetri informasi. Alasan yang menyebabkan tidak terdapat penurunan asimetri informasi setelah adopsi IFRS erat kaitannya dengan pasar modal di Indonesia yang kemungkinan karena adanya investor yang naif disebabkan mereka tidak mampu atau tidak bisa membedakan informasi yang bernilai ekonomis dan yang tidak bernilai ekonomis (Setiawan dan Hartono, 2003). Investor yang naif sering disebut investor yang price-protected yang biasanya hanya ikut-ikutan atau kurang paham dalam kebijakan akuntansi yang ada (Rahayu dan Cahyati, 2015). Investor yang naif bisa saja menyewa orang lain untuk menginterpetasi informasi atau meniru keputusan orang lain yang lebih paham. Selanjutnya, pasar modal tidak lepas dari asimetri informasi dikarenkan banyak para pengguna informasi mendapatkan informasi dari orang dalam atau dengan cara melalui perdagangan orang dalam atau yang lebih kita kenal dengan sebutan insider trading.

\section{Kesimpulan}

Berdasarkan hasil penelitian dan pembahasan yang telah dijelaskan sebelumnya, dapat disimpulkan bahwa:

1. Terjadi peningkatan relevansi informasi setelah pengadopsian IFRS, hal ini ditandai dengan peningkatan nilai relevansi yang dilihat dari peningkatan angka adjusted $R^{2}$ pada periode setelah adopsi IFRS.

2. Pengadopsian IFRS berpengaruh terhadap reliabilitas yang dilihat dari pengaruh ROA terhadap ABSDA, dan juga terjadi peningkatan reliabilitas yang dilihat dari penurunan angka ABSDA.

3. Setelah adopsi IFRS tidak terjadi penurunan asimetri informasi.

\section{Keterbatasan}

1. Penelitian ini hanya menggunakan periode pengamatan 2009-2014, sehingga tidak dapat menggambarkan hasil analisis terbaru pada tahun 2015.

2. Dalam hal menguji kualitas informasi, peneliti hanya mengambil kualitas informasi yang berupa relevansi dan reliabilitas.

3. Dalam hal menguji pengaruh pengadopsian IFRS terhadap relevansi informasi peneliti tidak mempertimbangkan variabel-variabel lain seperti tata kelola perusahaan dan konsentrasi tingkat kepemilikan sebagai pemoderasi hubungan pengadopsian IFRS dengan relevansi.

\section{Saran}

Berdasarkan hasil, pembahasan, kesimpulan dan keterbatasan pada penelitian ini, maka ada beberapa saran yang dapat diberikan agar penelitian selanjutnya memperoleh hasil yang lebih baik, yaitu:

1. Penelitian selanjutnya disarankan menggunakan periode penelitian yang lebih terkini dan runtut waktu, sehingga dapat diketahui informasi yang lebih terbaru mengenai peningkatan atau penurunan kualitas informasi laporan keuangan dan asimetri informasi setelah adanya adopsi IFRS.

2. Penelitian selanjutnya dalam hal menguji kualitas informasi sebaiknya menambahkan jenis kualitas informasi lain misalnya komparabilitas. Selain itu, penelitian selanjutnya mengenai kualitas 
informasi bisa melakukan penelitian dengan menggunakan dimensi lain seperti pengakuan kerugian tepat waktu (time loss recognition).

3. Penelitian selanjutnya yang akan menguji relevansi informasi setelah pengadopsian IFRS sebaiknya mempertimbangkan variabel-variabel lain seperti tata kelola perusahaan dan konsentrasi tingkat kepemilikan, karena variabel-variable tersebut termasuk hal yang mempengaruhi kualitas dari informasi akuntansi.

\section{Daftar Pustaka}

Amagoh, F. 2009. Information Asymmetry and The Contracting Out Process. The Innovation Journal: The Public Sector Innovation Journal. 14(2): 1-14.

Anas, Wahyuli D. 2014. Analisis Pengaruh Penerapan IFRS Terhadap Relevasi Nilai Informasi Akuntansi (Studi Empiris pada Perusahaan Manufaktur yang Terdaftar Di BEI 2009-2012). Skripsi. Padang: Universitas Negeri Padang.

Anthony, N. \& Vijay Govindarajan. 2005. Management Control Systems: Sistem Pengendalian Manajemen. Buku 2. Edisi 11. Terjemahan Kurniawan Tjakrawala. Jakarta: Salemba Empat.

Ayres, F. L. 1994. Perception of Earnings Quality: What Managers Need to Know?. Management Accounting Research.27-29.

Ball, R. 2006. International Financial Reporting Standards (IFRS): Pros and Cons for Investors. Accounting and Business Research, International Accounting Policy.. 36(Special Issue). 5-27.

Barth, M. E., W. R. Landsman., \&M. Lang. 2008. International Accounting Standards and Accounting Quality. Journal of AccountingResearch, 46, 467-498.

Barth, M.E., W.R. Landsman., M. Lang., \& C. Williams. 2009. Are International Accountingg Standards-Based and US GAAP-Based Accounting Amounts Comparable?. Center For Finance and Accounting Research. (Online), (mbarth@stanford.edu.). Diakses 1 Oktober 2015.

Botosan, A.Christine. 2000. Disclosure Level and Expected Cost of Equity Capital: An Examination of Analyst's Rankings of Corporate Disclosure.http://ssrn.com.

Cahyati, Ari D. 2011. Peluang Manajemen Laba Pasca Konvergensi IFRS: Sebuah Tinjauan Teoritis dan Empiris. Jurnal Akuntansi Keuangan. 2(1): 1-7.

Cahyonowati, N., \& D. Ratmono. 2012. Adopsi IFRS dan Relevansi Informasi Akuntansi. Jurnal Akuntansi dan Keuangan. 14(2): 105-115.

Callao, S., J. I. Jarne., J. A. Lainez. 2007. Adoption of IFRS in Spain: Effect on the comparability and relevance of financial reporting. Journal of International Accounting, Auditing and Taxation. 16: 148-178.

Chebaane, S. \& H.B. Othman. 2014. The Impact of IFRS adoption on Value Relevance of Earnings and Book Value of Equity: The Case of Emerging Markets in African and Asian Regions. Procedia-Social and Behavioral Sciences. 145: 70-80.

Chen. H., Q. Tang., Y. Jiang., \& Z. Lin. 2010. The Role of International Financial Reporting Standards in Accounting Quality: Evidence from the European.

Christensen, H. B., E. Lee., M. Walker., \& C. Zeng. 2016. Incentives or Standards: What Determines Accounting Quality Changes Around IFRS Adoption. European Accounting Review. 24(1): 31-61.

Christian, S. 2011. Faktor-Faktor yang Mempengaruhi Perataan Laba pada Perusahaan yang Terdaftar di Bursa Efek Indonesia. Skripsi. Semarang: Universitas Dipenogoro.

Dwimulyani, Susi. 2010. Relevansi Nilai Informasi Akuntansi Di Bursa Efek Indonesia. Jurnal Informasi, Perpajakan, Akuntansi dan Keuangan Publik. 5: 101-109

Edvandini, L., B. Subroto, \& E. Saraswati. 2014. Telaah Kualitas Informasi Akuntansi Sebelum 
dan Setelah Pengadopsian IFRS. Jurnal Akuntansi Multiparadigma. 5(1): 1-169.

Effendy, L., Nurazmi., \& L. Handajani. 2015. Dampak Adopsi IFRS Terhadap Manajemen Laba serta Peran Mekanisme Corporate Governance pada Perbankan Indonesia. SNA 18.

Fama, E. F. 1970. Efficient Capital Market: A Review of Theory and Empirical Work. The Journal of Finance. 25(2): 383-417.

Fanani, Z. 2009. Kualitas Pelaporan Keuangan: Berbagai Faktor Penentu dan Konsekuensi Ekonomis. Jurnal Akuntasi dan Keuangan Indonesia. 6(1):20-45.

Francis, J. \& K. Schipper. 1999. Have Financial Statements Lost Their Relevance?, Journal of Accounting Research. 37(2): 319-52.

Gassen, J. \& T. Sellhorn. 2006. Applying IFRS in Germany- Determinants and Consequances. Betriebswirtschaftliche Forschung und Praxis. 58(4): 1-38.

Ghozali, Imam. 2011. Aplikasi Analisis Multivarite dengan Program SPSS. Semarang: Badan Penerbit Universitas Diponegoro.

Goncharov, I. \& J. Zimmerman.2006. Do Accounting Standard Influence The Level of Earnings Management ? Evidence from Germany. (Online)

(http://papers.ssrn.com/sol3/papers.cfm?abstrac $\underline{t i d=386521}$ ). Diakses pada tanggal 7 Januari 2016.

Gujarati, D. 2003. Basic Econometric. Mc-Grawhill. New York.

Halim, J., C. Meiden., \& R. L. Tobing. 2005. Pengaruh Manajemen Laba pada Tingkat Pengungkapan Laporan Keuangan pada Perusahaan Manufaktur yang termasuk dalam Indeks LQ45. SNA 8. Solo

Harahap, Sofyan S. 2011. Teori Akuntansi. Jakarta: Raja Grafindo Persada.

Hendriksen, Eldon S. \& Michael F. Van Breda. 2002. Teori Akuntansi. Buku 2. Terjemahan Herman Wibowo. Batam: Interaksara.
Hung, M. \& Subramanyam, K.R. (2007). Financial Statement Effects of Adopting International Accounting Standards, The Case of Germany. Review of Accounting Standards. 12(4): 623657.

Icih, \& I. Fikrotusshohah. 2014. Analisis Kualitas Informasi Akuntansi Sebelum dan Sesudah Adopsi Penuh International Financial Reporting Standard (IFRS) (Studi Kasus Pada Perusahaan Manufaktur yang Terdaftar Di Bursa Efek Indonesia Periode 2010-2013). Proceedings SNEB.

Ifonie, Regina R. 2012. Pengaruh Asimetri Informasi dan Manajemen Laba Terhadap Cost of Equity Capital Pada Perusahaan Real Estate yang terdaftar Di Bursa Efek Indoesia. Jurnal Ilmiah Mahasiswa Akuntansi. 1(1): 103-107.

Iatridis, G. 2010. International Financial Reporting Stadards and The Quality of Financial Statement Information. International Review of Financial Analysis. 19: 193-204.

Ikatan Akuntan Indonesia. 2015. Standar Akuntansi Keuangan. Jakarta: Salemba Empat.

Indriantoro, Nur \& Bambang Supomo. 2002. Metodologi Penelitian Bisnis.Edisi pertama. Yogyakarta: BPFE-Yogyakarta.

International Accounting Standard Board (IASB). 2008. Exposure Draft of An Improved Conceptual Framework for Financial Reporting. IASB

Jensen, Michael C. \& W.H. Meckling. 1976. Theory of The Firm: Managerial of Behaviour, Agency Cost, and Ownership Structure. Journal of Financial Economics. 3(4): 305-360.

Kargin, S. 2013. The Impact of IFRS on The Value Relevance of Accounting Information: Evidence from Turkish Firms. International Journal of Economics and Finance. 5(4): 71-80.

Keown, A., D. Scott., J.D. Martin., \& J.W. Petty. 2002. Basic Financial Management. Edisi 8. USA: Prentice-Hall International.

Khajar, I. 2008. Pengujian Efisiensi dan Peningkatan Efisiensi Bentuk Lemah Burs Efek Indonesia Pada Saat dan Sesudah Krisis Moneter Pada 
Saham-Saham LQ-45. National Conference on Management Research.

Khanagha, J. B. 2011. Value Relevance of Accounting Information in the United Arab Emirates. International Journal of Economics and Financial Issues.1(2): 33-45.

Kieso, Donald E., Jerry J. Weygandt, \& Terry D. Warfield. 2007. Intermediate Accounting. $12^{\text {th }}$ Ed. Hoboken, NJ:John wiley \& Sons.

Krismiaji, Y. A. Aryani.\& D. Suhardjanto. 2013. Pengaruh International Financial Reporting Standard Terhadap Kualitas Informasi Akuntansi. Jurnal Akuntansi dan Manajemen. 24(2): 63-71.

Leuz, C. 2003. IAS Versus US GAAP: Information Asymmetri-Based Evidence From Germany's New Market. The Joural of Accounting Research. 1-43.

Marati, F.S. 2012. Analisis Efisiensi Pasar Modal Indonesia. Jurnal Ilmu Manajemen Dan Akuntansi Terapan. 3(2).

Melinda. 2014. Pengaruh Penerapan SAK (Konvergensi IFRS) Terhadap Kualitas Informasi Laporan Keuangan. Skripsi. Padang: Universitas Negeri Padang.

Morais, A. I. Dan J. D. Curto. 2008. Accounting Quality and The Adoption of IASB StandardsPortuguese Evidence. SSRN Working Paper.(Online), (http://dx.doi.org/10.1590/S151970772008000300009). Diakses 3 Januari 2016.

Muller, K.A.I, E.J. Riedl dan T. Sellhorn. 2011. Consequences of Voluntary and Mandatory Fair Value Accounting: Evidence Surrounding IFRS Adoption in the EU Real Estate Industry. Harvard Business School Working Paper 9-33.

Novianto, R.A., \& N. Cahyonowati. 2014. Pengaruh Konvergensi IFRS Terhadap Asimetri Informasi (Study Kasus Pada Perusahaan Real Estate Di Indonesia). Diponogoro Journal Of Accounting. $3(2): 1-8$

Nugrohadi, Anggi P. 2014. Implementasi IFRS Terhadap Kinerja Keuangan. Skripsi. Semarang: Universitas Dipenogoro.
Nuryatno, M., N. Nazir., \& M. Rahmayanti. 2007. Hubungan Antara Pengungkapan, Informasi Asimetri, dan Biaya Modal. Jurnal Informasi, Perpajakan, Akuntansi,dan Keuangan Publik. 2(1):9-26.

Ohlson, J. A. 1995. Earnings, Book values, and Dividendsin equity Valuation. Contemporary Accounting Research. 11: 661-687.

Palea, V. 2013. IAS/IFRS and financial reporting quality: Lessons from the European experience. China Journal of Accounting Research. 6: 247263.

Rahayu, R. \& A.D. Cahyati. 2015. Komparasi Asimetri Informasi Sebelum dan Sesudah Konvergensi IFRS. Jurnal Akuntansi Keuangan. 25-40.

Rahmawati, L.\& H. Murtini. 2015. Kualitas Informasi Akuntansi Pra Dan Pasca Adopsi IFRS. Accounting Analysis Journal.4(2): 1-9.

Saito, M \& S. Mayangsari. 2009.The Influences of International Accounting Standards On Earning Quality: Case In Japan. SNA 12 Palembang.133.

Sarwono, Jonathan. 2008. Metodologi Penelitian Kuantitatif dan Kualitatif. Yogyakarta: Graha Ilmu.

Scott, William R. 1997. Financial Accounting Theory. New Jersey: Prentice-Hall Inc.

Sekaran, Uma. 2006. Research Methods For Business:Metodologi Penelitian Untuk Bisnis. Buku 1. Edisi 4. Terjemahan Kwan Men Yon. Jakarta: Salemba Empat.

Sianipar, Glory. 2013. Analisis Komparasi Kualitas Informasi Sebelum dan Sesudah Pengadopsian Penuh IFRS Di Indonesia (Studi Empiris pada Perusahaan Manufaktur yang Terdaftar Di BEI Tahun 2011-2012). Semarang: Universitas Dipenogoro.

Soewardjono. 2011. Teori Akuntansi Perekayasaan dan Pelaporan Keuangan. Edisi 3. Yogyakarta: BPFE Yogyakarta.

Suprihatin, S.\& E. Tresnaningsih. 2013. Dampak Konvergensi International Financial Reporting 
Standard Terhadap Nilai Relevan Akuntansi. Jurnal Akuntansi dan Keuangan.10(2): 171-183.

Tandelilin, Eduardus. 2010. Analisis Investasi Dan Manajemen Portofolio. Edisi Pertama. Yogyakarta: BPFE Yogyakarta.

Tsalavoutas, I., P. Andre., \& L. Evans. 2012. The Trantition to IFRS and The Value Relevance of Financial Statements In Greece. The British Accounting Review. 44: 262-277.Union. Journal of International Financial Management \& Accounting. 21(3)

Wahidah, U. \& S. Ayem. 2014. Pengaruh Pengadopsian IFRS Terhadap Kualitas Informasi Akuntansi Pada Perusahaan Yang Terdatar Di Bursa Efek Indonesia. Syariah Paper Accounting. 3(1): 327-337.

Wulandari, T.R. \& AAS Surakarta. 2013. Perubahan Value Relevance Dalam Informasi Akuntansi Setelah Adopsi IFRS: Bukti Perusahaan Manufaktur. Jurnal Akuntansi dan Pajak. 13(2): 47-60.

Yang, I.H., B. Karthik., \& L. Xi. 2013. Mandatory Financial Reporting Environment and Voluntary Disclosure: Evidence from Mandatory IFRS Adoption. Research Collection School Of Accountancy.(online), (http://ink.library.smu.edu.sg/soa research/1163 ). Diakses 4 Februari 2016. 